\title{
ForTHCOMING CONFERENCES
}

The Canadian Society for Syriac Studies

\section{AMIR HARRAK, UNIVERSITY OF TORONTO}

[1] The purpose of this Society, which has been recently established at the University of Toronto, is to stimulate interest among the general public in the history, archaeology and culture of the Syriacspeaking people: Assyrians, Chaldeans, Maronites, Orthodox and Catholic Syriacs. The Society is a non-profit organization with no political or ideological affiliations or functions. Its areas of activity are: Public lectures and symposia, archaeology, research, films and music, exhibitions, evening courses, and travel.

\section{Public Lectures for the Year 2000-2001}

[2] Exact dates and titles will be announced in due time.

NOVEMBER 2000

Recent Archaeological Excavations in Takrit and the Discovery of Syriac Inscriptions, by Prof. A. Harrak, Near \& Middle Eastern Civilizations, University of Toronto.

\section{JANUARY 2001}

(Syriac Art and Inscriptions in the Monastery of the Syrians in Egypt), by Prof. Lucas van Rompay, Duke University.

\section{MARCH 2001}

(Excavating an East Syriac Church in Kyrgyzstan), by Dr. Wassilios Klein, University of Bonn.

\section{Membership}

[3] Membership in the Society includes free admission to lectures, the annual symposium, and Member's receptions, as well as subscriptions to the CSSS Bulletin, which will include the transcripts of the public lectures. Please make cheques payable to: Canadian Society for Syriac Studies Inc. and mail them to the address given below. Outside Canada payment is made in US dollars. 


$\begin{array}{ll}\text { Annual regular membership } & \$ 35 \\ \text { Sponsorship, from } & \$ 450 \\ \text { Life membership } & \$ 500 \\ \text { Corporate membership (per year) } & \$ 250\end{array}$

\section{Address}

[4] The Canadian Society for Syriac Studies Inc.

c/o Department of Near and Middle Eastern Civilizations

University of Toronto

4 Bancroft Avenue

Toronto, Ontario, Canada M5S 1C1

E-mail: aharrak@chass.utoronto.ca

Tel. 416/978-3184

FAX 416/978-3305 